\title{
Managing Multiple Vital Rates to Maximize Greater Sage-Grouse Population Growth
}

\author{
REBECCA L. TAYLOR, ${ }^{\mathbf{1 , 2}}$ Wildlife Biology Program, College of Forestry and Conservation, University of Montana, 32 Campus Drive, Missoula, \\ MT 59812, USA \\ BRETT L. WALKER, ${ }^{3}$ Wildlife Biology Program, College of Forestry and Conservation, University of Montana, 32 Campus Drive, Missoula, \\ MT 59812, USA \\ DAVID E. NAUGLE, Wildlife Biology Program, College of Forestry and Conservation, University of Montana, 32 Campus Drive, Missoula, \\ MT 59812, USA \\ L. SCOTT MILLS, Wildlife Biology Program, College of Forestry and Conservation, University of Montana, 32 Campus Drive, Missoula, \\ MT 59812, USA
}

\begin{abstract}
Despite decades of field research on greater sage-grouse, range-wide demographic data have yet to be synthesized into a sensitivity analysis to guide management actions. We reviewed range-wide demographic rates for greater sage-grouse from 1938 to 2011 and used data from 50 studies to parameterize a 2 -stage, female-based population matrix model. We conducted life-stage simulation analyses to determine the proportion of variation in population growth rate $(\lambda)$ accounted for by each vital rate, and we calculated analytical sensitivity, elasticity, and variance-stabilized sensitivity to identify the contribution of each vital rate to $\lambda$. As expected for an upland game bird, greater sage-grouse showed marked annual and geographic variation in several vital rates. Three rates were demonstrably important for population growth: female survival, chick survival, and nest success. Female survival and chick survival, in that order, had the most influence on $\lambda$ per unit change in vital rates. However, nest success explained more of the variation in $\lambda$ than did the survival rates. In lieu of quantitative data on specific mortality factors driving local populations, we recommend that management efforts for greater sage-grouse first focus on increasing female survival by restoring large, intact sagebrush-steppe landscapes, reducing persistent sources of human-caused mortality, and eliminating anthropogenic habitat features that subsidize species that prey on juvenile, yearling, and adult females. Our analysis also supports efforts to increase chick survival and nest success by eliminating anthropogenic habitat features that subsidize chick and nest predators, and by managing shrub, forb, and grass cover, height, and composition to meet local brood-rearing and nesting habitat guidelines. We caution that habitat management to increase chick survival and nest success should not reduce the cover or height of sagebrush below that required for female survival in other seasons (e.g., fall, winter). The success or failure of management actions for sage-grouse should be assessed by measuring changes in vital rates over long time periods to avoid confounding with natural, annual variation. (c) 2011 The Wildlife Society.
\end{abstract}

KEY WORDS Centrocercus urophasianus, demography, greater sage-grouse, life-stage simulation analysis, nest success, population growth, process variance, sagebrush, sensitivity, survival.

Knowledge of life history traits and vital rates that influence population growth is crucial for maximizing the effectiveness of conservation and management of sensitive or declining wildlife species. Greater sage-grouse (Centrocercus urophasianus, sage-grouse) are upland game birds native to sagebrush (Artemisia spp.) communities of western North America (Schroeder et al. 1999). Degradation of sagebrush commu-

Received: 28 July 2010; Accepted: 27 June 2011;

Published: 18 November 2011

Additional Supporting Information may be found in the online version of this article.

${ }^{1}$ E-mail: rebecca.taylor@cfc.umt.edu

${ }^{2}$ Present Address: USGS Alaska Science Center, 4210 University Drive, Anchorage, AK 99508, USA.

${ }^{3}$ Present Address: Colorado Division of Wildlife, 711 Independent Avenue, Grand Junction, CO 81505, USA. nities has contributed to declines in sage-grouse populations and to extirpation of the species from almost half of its original range (Schroeder et al. 2004). The severity and extent of such changes have led to heightened concern over the species' population status and recent listing of the species as warranted but precluded under the Endangered Species Act (United States Fish and Wildlife Service 2010). It has also precipitated efforts by local working groups, private landowners, state and federal agencies, and industry to improve habitat and to assess and ameliorate risks to populations throughout their range (Connelly and Braun 1997, Connelly et al. 2004, Aldridge et al. 2008).

Conservation and management efforts are most likely to succeed when they focus on increasing vital rates that most strongly influence population growth (Wisdom et al. 2000, Reed et al. 2009). Habitat management for many galliforms 
focuses on improving nest success and chick survival because those vital rates generally are thought to drive population growth in most upland game birds (Bergerud 1988, Wisdom and Mills 1997, Clark et al. 2008, Devers et al. 2009). The concept that productivity regulates population growth is widely cited in studies of sage-grouse reproductive biology (e.g., Drut et al. 1994, Holloran et al. 2005, Huwer et al. 2008); however, sage-grouse have larger body size, smaller clutch sizes, lower renesting rates, higher annual survival, and a longer life span than many other upland game birds (Arnold 1988, Jönsson et al. 1991, Zablan et al. 2003, Hagen et al. 2005). In birds, these life history traits are more commonly associated with "survivor" species, in which survival parameters are more important for population growth, rather than "highly reproductive" species, in which reproductive parameters take precedence (Sæther et al. 1996, Sæther and Bakke 2000, Stahl and Oli 2006). Although galliforms as a group are highly reproductive compared to many other groups of longer-lived birds (e.g., procelliform seabirds), sage-grouse life history traits appear to put them on the "survivor" end of the spectrum within the galliforms. Thus, management emphasis on increasing survival may be warranted compared to other upland game species. The importance of survival parameters to sage-grouse populations has been suggested in previous studies of the effects of harvest on populations (Connelly et al. 2000a, 2003; Sika 2006; Reese and Connelly 2011). However, the relative importance of survival versus reproductive parameters for population growth in sage-grouse at a range-wide scale has never been quantified.

Analyses of species' demographics and life history, including sensitivity analyses of matrix population models, are valuable for identifying which vital rates have the greatest influence on population growth, which show the most variability, and which should be targeted by managers (Wisdom et al. 2000, Reed et al. 2002, Koons et al. 2006, Mills 2007). Sensitivity analyses have been conducted to inform management of numerous species of economic value or conservation concern, including sea turtles (Crouse et al. 1987), tortoises (Reed et al. 2009), amphibians (Biek et al. 2002), waterfowl (Hoekman et al. 2002, Koons et al. 2006, Coluccy et al. 2008), big game (Raithel et al. 2007, Johnson et al. 2010), upland game birds (Clark et al. 2008, Sandercock et al. 2008, Devers et al. 2009), and migratory waterbirds (Grear et al. 2009). Despite extensive research on sage-grouse demography, there has been no synthesis of demographic and life history data into a comprehensive population model, nor have sensitivity analyses been used at a range-wide scale to identify key vital rates and inform management decisions. Several authors have summarized basic sage-grouse population parameters (Schroeder et al. 1999; Connelly et al. 2000b, 2011; Schroeder 2000; Crawford et al. 2004). Others have used matrix models based on local demographic data to assess impacts of potential stressors (e.g., hunting, natural gas development, West Nile virus) on population growth and to make management recommendations for specific populations (Johnson and Braun 1999, Holloran 2005, Walker 2008, Dahlgren 2009). However, for species like sage-grouse, in which vital rates can vary substantially among sites and years, short-term studies may not be representative of the life history and population dynamics of the species as a whole.

Objectives of this article are to: 1) summarize sage-grouse vital rates throughout the species' range, 2) identify research needs for demographic data, 3) assess the relative importance of stage-specific vital rates for population growth, and 4) compare the effectiveness of targeting different sets of vital rates to increase population growth through management.

\section{METHODS}

\section{Literature Review and Data Filtering}

We reviewed documents from all states and provinces throughout the species' current range in western North America (Schroeder et al. 2004). We obtained vital-rate data on sage-grouse populations by systematically searching the databases Google Scholar, Academic Search Premier, Biological Abstracts, BioOne, CSA Biological Sciences, Environment Complete, Wildlife and Ecology Studies Worldwide, Dissertation Abstracts, JSTOR, and Zoological Record. We used combinations of primary (sage-grouse, sage grouse, Centrocercus, and Centrocercus urophasianus) and secondary keywords (clutch size, nesting, nest success, chick survival, and survival). We checked original references cited in previous demographic summaries (Schroeder et al. 1999; Connelly et al. 2000b, 2011; Schroeder 2000; Crawford et al. 2004) to ensure no studies were overlooked. References reviewed included published journal articles, theses, dissertations, and unpublished agency reports spanning the years 1938-2011 (Appendix A, Supplemental Material, available online at www.onlinelibrary.wiley.com). For recent studies (2003 and later) that contained relevant data but for which estimates either could not be extracted or were incompatible with our model structure, we requested year-, stage-, or nest attempt-specific estimates directly from the authors. We reviewed vital rate data from 104 studies, and we included data from 50 of these in the analyses (Appendix A, Supplemental Material, available online at www.onlinelibrary.wiley.com).

Among the 104 studies with relevant data, we excluded data from those with known bias. We excluded all data from translocation studies because translocated birds unfamiliar with new habitat are likely to reproduce and survive at lower rates (Musil et al. 1993, Reese and Connelly 1997, Baxter et al. 2008). We excluded survival data from studies using poncho or wing-tagged birds (e.g., Wallestad 1975) because these highly visible markers may increase detectability to predators. We also excluded survival data from studies in which West Nile virus mortality affected estimates (e.g., Swanson 2009) because mortality events associated with this novel virus are outliers compared to mortality rates from the seven previous decades. Furthermore, the sensitivity of sage-grouse population growth rate to West Nile virus has already been examined (Walker and Naugle 2011). With a few exceptions, we included data in our analyses only if they were sex-, stage-, and nest attempt-specific. We used 
estimates of hatching success averaged across stages and nest attempts because no studies presented stage- or attemptspecific data. We used stage-specific chick survival data from hatch to 35 days when it was available (2 studies), but we maximized use of available data for this life stage by including data from studies providing non-stage specific estimates as well. No studies distinguished male from female chicks, so all estimates of chick survival to 35 days represent survival for both sexes combined.

\section{Matrix Model}

We developed a 2-stage, female-based life-cycle model to summarize demographic rates for yearling and adult sagegrouse. We used estimates of stage-specific vital rate means and associated process variances derived from range-wide data (Table 1) to parameterize probability density functions for each vital rate. From these, we simulated 10,000 sets of vital rates and used them to create $10,0002 \times 2$ stagespecific population matrices based on a pre-breeding, birth-pulse census and a 1-yr time step (Appendix B, Supplemental Material, available online at www.onlinelibrary.wiley.com). All analyses were done in program $\mathrm{R}$, version 2.10.0 ( $\mathrm{R}$ Foundation for Statistical Computing, Vienna, Austria).

\section{Sensitivity Analyses}

To maximize our ability to recommend efficient management actions, we analyzed the data using several different sensitivity metrics within a Life-stage Simulation Analysis (LSA) framework across 10,000 replicate matrices (Wisdom et al. 2000, Hoekman et al. 2002, Mills 2007). To identify how much population growth rate $(\lambda)$ changes with a small, unit change in each vital rate, we calculated analytical sensitivity, elasticity, and variance-stabilized sensitivity (VSS; Link and Doherty 2002) for each of the replicate, simulated matrices. These 3 metrics are all first partial derivatives, but they provide different information because they are calculated using different data transformations. Sensitivity uses raw data, and represents the change in $\lambda$ when a fixed amount is added to a vital rate. Elasticity uses $\log -\log$ transformed data, and represents the proportional change in $\lambda$ due to a proportional change in a vital rate. Our VSS used a log transformation on population growth rate and $2 \times$ arcsine square root transformation on each vital rate.

We also used LSA to determine the proportion of variation in $\lambda$ accounted for by each vital rate. We calculated the coefficient of determination $\left(R^{2}\right)$ for each vital rate based on a simple linear regression of population growth rate on each vital rate from all 10,000 replicate matrices. Coefficients of determination in LSA regressions identify vital rates that have high variance, large effects on $\lambda$ (as measured by the slope of the regression line), or both. To make coefficients of determination directly comparable to the analytical metrics, we conducted regressions on untransformed data to compare to sensitivity, on $\log -\log$ transformed data to compare to elasticity, and on the $\log -2 \times$ arcsine square root transformed data to compare to VSS.

We also summed sensitivity metrics across similar vital rates to identify key groups of vital rates that should be prioritized by managers. As an example, we grouped juvenile female survival with yearling and adult female survival (female survival) because juveniles flock with yearlings and adults during the majority of the 8-9-month juvenile period,

Table 1. Estimated means and process variances (with $95 \% \mathrm{CIs}$ ) from bootstrapping of range-wide vital rates from 50 studies used in population modeling for yearling and adult sage-grouse, 1938-2011.

\begin{tabular}{|c|c|c|c|c|}
\hline \multirow[b]{2}{*}{ Vital rate $^{\mathrm{a}}$} & \multicolumn{2}{|c|}{ Mean } & \multicolumn{2}{|c|}{ Process variance } \\
\hline & Expected value & $95 \% \mathrm{CI}$ & Expected value & $95 \% \mathrm{CI}$ \\
\hline $\mathrm{I}_{1 \mathrm{y}}$ & 0.89 & $(0.87,0.91)$ & 0.0231 & $(0.0202,0.0405)$ \\
\hline $\mathrm{I}_{1 \mathrm{a}}$ & 0.96 & $(0.94,0.97)$ & 0.0103 & $(0.0061,0.0269)$ \\
\hline $\mathrm{I}_{2 \mathrm{y}}$ & 0.18 & $(0.14,0.22)$ & 0.0320 & $(0.0257,0.0716)$ \\
\hline $\mathrm{I}_{2 \mathrm{a}}$ & 0.43 & $(0.39,0.47)$ & 0.0489 & $(0.0459,0.0778)$ \\
\hline $\mathrm{I}_{3 \mathrm{a}}$ & 0.12 & $(0.06,0.19)$ & 0.0017 & $(0.0000,0.0483)$ \\
\hline $\mathrm{CL}_{1 \mathrm{y}}$ & 3.78 & $(3.62,3.95)$ & 0.0154 & $(0.0128,0.2281)$ \\
\hline $\mathrm{CL}_{1 \mathrm{a}}$ & 4.10 & $(3.96,4.23)$ & 0.0200 & $(0.0132,0.1662)$ \\
\hline $\mathrm{CL}_{2 \mathrm{y}}$ & 3.09 & $(2.69,3.42)$ & 0.0010 & $(0.0000,0.1444)$ \\
\hline $\mathrm{CL}_{2 \mathrm{a}}^{2 \mathrm{a}}$ & 3.29 & $(2.98,3.53)$ & 0.0010 & $(0.0000,0.1444)$ \\
\hline $\mathrm{CL}_{3 \mathrm{a}}$ & 2.79 & $(2.48,3.03)$ & 0.0010 & $(0.0000,0.1444)$ \\
\hline $\mathrm{HCH}$ & 0.92 & $(0.91,0.94)$ & 0.0017 & $(0.0009,0.0046)$ \\
\hline $\mathrm{NS}_{1 \mathrm{y}}$ & 0.38 & $(0.34,0.42)$ & 0.0365 & $(0.0349,0.0702)$ \\
\hline $\mathrm{NS}_{1 \mathrm{a}}$ & 0.44 & $(0.41,0.48)$ & 0.0274 & $(0.0254,0.0535)$ \\
\hline $\mathrm{NS}_{2 \mathrm{y}}$ & 0.44 & $(0.27,0.62)$ & 0.0569 & $(0.0146,0.1745)$ \\
\hline $\mathrm{NS}_{2 \mathrm{a}, 3 \mathrm{a}}$ & 0.53 & $(0.46,0.61)$ & 0.0326 & $(0.0145,0.0922)$ \\
\hline $\mathrm{CHSV}_{\mathrm{y}}$ & 0.41 & $(0.39,0.43)$ & 0.0182 & $(0.0158,0.0291)$ \\
\hline $\mathrm{CHSV}_{\mathrm{a}}$ & 0.41 & $(0.39,0.43)$ & 0.0129 & $(0.0107,0.0221)$ \\
\hline $\mathrm{JSV}_{1}$ & 0.75 & $(0.67,0.82)$ & 0.0084 & $(0.0000,0.0385)$ \\
\hline $\mathrm{JSV}_{2,3 \mathrm{a}}$ & 0.73 & $(0.65,0.80)$ & 0.0078 & $(0.0000,0.0389)$ \\
\hline $\mathrm{SV}_{\mathrm{y}}$ & 0.65 & $(0.61,0.69)$ & 0.0141 & $(0.0113,0.0379)$ \\
\hline $\mathrm{SV}_{\mathrm{a}}$ & 0.58 & $(0.54,0.61)$ & 0.0031 & $(0.0019,0.0201)$ \\
\hline
\end{tabular}

${ }^{a}$ I, nest initiation rate; CL, clutch size (female eggs only); NS, nest success; HCH, hatching rate; CHSV, survival of chicks from hatch to 35 days; JSV, survival of juveniles from 35 days of age to the start of the breeding season in their second year (approx. 1 April); SV, annual survival of females. Subscripts indicate nesting attempt (1-3) and stage (a, adult; y, yearling). When data were too sparse to estimate a vital rate as stage- and nest attempt-specific, the same mean and variance were used to represent the different stages or nest attempts. See Appendix B, Supplemental Material, available online at www.onlinelibrary.wiley.com for details. 
and they use the same summer, fall, and winter habitats and therefore should be affected similarly by management actions. We grouped first nest initiation rates for both stage classes (first nest initiation rate), renesting rates for both stage classes (renest initiation rate), clutch sizes for both stage classes and all nesting attempts (clutch size), nest success for both stage classes and all nesting attempts (nest success), hatching rate for both stage classes and all nesting attempts (hatching rate), and chick survival for both stage classes and all nesting attempts (chick survival). To present a summary, we averaged each summed analytical metric across all 10,000 matrices, and we present analytical metrics and $R^{2}$ values on the same graphs to simultaneously illustrate the effect of each group of vital rates on $\lambda$ as well as the strength of those relationships. To provide managers with an intuitive feel for the changes in $\lambda$ arising from the small, equal changes measured by analytical sensitivity, we manually perturbed each of 3 important groups of vital rates by adding 0.1 to the mean rate, demonstrating how much population growth rate would change if management actions could increase each of these rates by an equivalent amount.

Population growth rate in our analyses is calculated as an eigenvalue, and as such, rests on the assumption that vital rates are constant for a time period long enough for simulated populations to converge to stable stage distribution. Although sage-grouse vital rates vary from year to year, and we would have preferred to not assume stable stage distribution (Fefferman and Reed 2006, Johnson et al. 2010), we lacked the empirical initial stage distributions required to avoid this assumption. In trial simulations, our mean matrix converged to stable stage distribution in just 2 time steps, regardless of the stage distribution of the starting population vector, so we felt this assumption was a reasonable approximation.

\section{Estimating the Mean and Process Variance of Vital Rates}

We described each vital rate that is a probability (e.g., survival or nest success as opposed to clutch size) with a beta distribution because the beta distribution has a flexible shape and is bounded by 0 and 1 . Each beta distribution was parameterized with an overall mean and a process variance calculated from the range-wide data in our literature review (Wisdom et al. 2000). This method is based on the idea that each sage-grouse population has a mean vital rate, and that these population means are related to each other via a probability distribution. The grand mean of the population means is the range-wide mean vital rate, and the variation among the population means is the process variance.

We estimated the mean and process variance of each rate using a mixed effects model with a fixed intercept and random effects, because the fixed intercept $\left(B_{0}\right)$ estimates the range-wide mean, each random effect represents an addition (or subtraction) to the range-wide mean to yield each population mean, and the variance of the random effects $\left(\sigma^{2}\right)$ estimates the process variance. In particular, we fit to the data a generalized mixed effects logistic regression with a fixed intercept, 2 random effects (site and year-within-site) and binomial sampling error, using package lme4 in Program $\mathrm{R}$ (Bolker et al. 2008). Mixed effects logistic linear models assume that the logits of the population means are normally distributed. Therefore, to transform from the logit scale to the probability scale, we sampled logits 10,000 times from an $N\left(B_{0}, \sigma^{2}\right)$ distribution, transformed each random variate to the probability scale, and calculated the sample mean and variance of these 10,000 probabilities.

Although it is possible, in some situations, to determine how much variance is due to each of the random effects, this was not possible with our data for a combination of reasons. First, sage-grouse vital rates vary markedly among years, even at the same site, and they vary markedly among sites, even during the same year. Furthermore, uneven sampling across sites and years in the range-wide data confounded these 2 sources of variation, preventing us from estimating how much process variance was due to site versus how much was due to year. However, we were able to reliably estimate total process variance as the sum of the variances of the 2 random effects. This is akin to considering each site-year a population. By estimating combined spatial and temporal variation in sage-grouse vital rates, we captured the large natural variability in these rates without making unrealistic or unsupported assumptions about how much variation was due to site versus year.

We described mean clutch sizes with stretched beta distributions because they can be bounded by values other than 0 and 1 (Morris and Doak 2002). We estimated the mean of each stretched beta distribution with the sample mean over site-years from range-wide data. We estimated process variance in mean clutch size using a method consistent with our process variance estimation for other rates (Appendix C, Supplemental Material, available online at www.onlinelibrary.wiley.com).

We obtained confidence intervals on all vital rate means and process variances using non-parametric bootstrapping (Efron and Tibshirani 1998). Because the sites and years studied, as well as the number of birds sampled at each site, were not derived from a comprehensive sampling design, we used case-based bootstrapping, in which each individual bird (or her nest or clutch) was considered a case, and site and year were covariates specific to each bird.

\section{Correlations Among Vital Rates}

We conducted sensitivity analyses with and without correlations among vital rates to see how correlation structure influenced rankings of vital rates and sensitivity metrics. Because the nature of the range-wide dataset prohibited estimating an empirical correlation matrix, we instead created a non-negative definite correlation matrix by assigning each pair of vital rates a correlation coefficient that was either low and negative $(-0.25)$, zero, low and positive $(0.25)$, or moderate and positive (0.50), based on potential life history tradeoffs between vital rates (negative correlations) or vital rates responding similarly to the same biological mechanisms (positive correlations). 


\section{Evaluating Data Limitations}

Because of data limitations, we may have underestimated the process variance for mean clutch size and juvenile survival, and we may have misestimated the mean for juvenile survival. To evaluate the effects of these limitations on our results, we reran the sensitivity analyses under each of the following 4 assumptions: 1) process variance in mean clutch size is 50\% larger than the estimate, 2) process variance in juvenile survival is $50 \%$ larger than the estimate, 3 ) mean juvenile survival is $15 \%$ less than the estimate, and 4) mean juvenile survival is $15 \%$ higher than the estimate.

\section{RESULTS}

\section{Summary of Vital Rates}

Mean first nest initiation rates (Table 1) were greater for adults $(0.96$ [CI: 0.94, 0.97]) than for yearlings (0.89 [CI: $0.87,0.91]$ ), although both rates are underestimated because not all apparent nest initiation rates could be adjusted to account for females whose nests failed prior to detection (Appendix B, Supplemental Material, available online at www.onlinelibrary.wiley.com). Adults were $>2 \times$ as likely to renest after the failure of a first nest $(0.43$ [CI: 0.39, $0.47])$ than were yearlings $(0.18$ [CI: $0.14,0.22])$. Only adults have been documented to attempt a third nest following a failed second nest, albeit at a low average rate $(0.12$ [CI: $0.06,0.19]$ ). Mean clutch sizes (female eggs only) varied by stage and nest attempt, from a low of 2.79 (CI: 2.48, 3.03) for adult third nests to a high of 4.10 (CI: 3.96, 4.23) for first nests of adults. Within first nests, mean clutch size was larger for adults than for yearlings, and within each age group, mean clutch size was larger for first nests than for second nests. Mean nest success ranged from 0.38 (CI: 0.34, 0.42) for first nests of yearlings to 0.53 (CI: $0.46,0.61$ ) for renests of adults. Nest success appears to be greater for adults than for yearlings and, within each age group, greater for renests than for first nests; however, not all differences were significant. Yearling females survived at greater annual rates than did adult females: 0.65 (CI: $0.61,0.69$ ) versus 0.58 (CI: 0.54, 0.61). Mean asymptotic population growth rate across 10,000 simulated matrices was $1.10 \pm 0.18$ (mean $\pm \mathrm{SD}$ ). Incorporating low to moderate vital rate correlations did not substantially change mean growth rate, but the standard deviation of growth rates increased to 0.26 . Generation time, calculated as the time required for the population to increase by a factor of $R_{0}$ (the net reproductive rate, or the expected number of female offspring a female will produce over her lifetime; Caswell 2001), was estimated at $2.56 \pm 0.46$ yr (mean $\pm \mathrm{SD})$.

\section{Sensitivity Analyses}

Female survival had the greatest mean value for sensitivity (1.70) and elasticity (1.00), and chick survival ranked second (1.20 for sensitivity; 0.42 for elasticity; Fig. 1). Adding 0.1 to mean rates caused $\lambda$ to increase by 0.17 for female survival, by 0.12 for chick survival, and by 0.09 for nest success. Vital rates associated with first nesting attempts had summed analytical metrics $>4 \times$ greater than those associated with renesting attempts ( 3.40 vs. 0.83 for sensitivity, 2.10 vs. 0.44
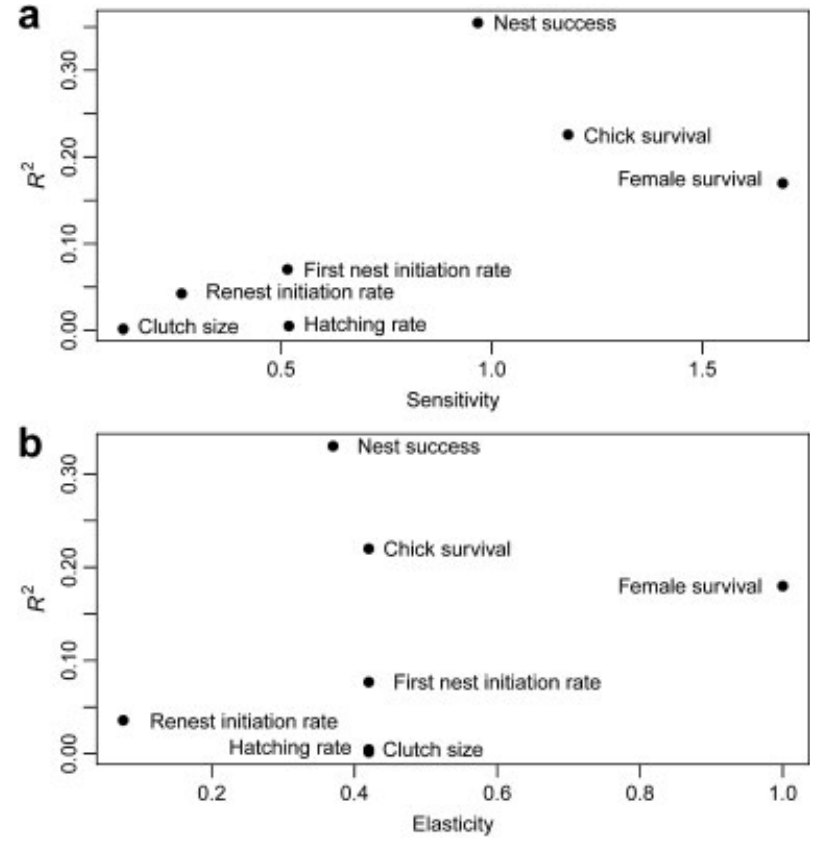

Figure 1. $R^{2}$ versus (a) sensitivity which uses raw data and (b) elasticity which uses $\log -\log$ transformed data from a sage-grouse life-stage simulation analysis using 10,000 simulated matrices derived from range-wide data, 1938-2011. The $R^{2}$ values, describing the proportion of variation in population growth rate attributable to each vital rate, were obtained using the same transformation used to obtain the analytical metrics on the same plot. Female survival represents juvenile, yearling, and adult survival combined. Chick survival represents survival of chicks from all successful nests and renests of yearling and adult females combined. Nest success represents success of all nesting attempts of yearling and adult females combined. First nest initiation rate and renest initiation rate are for all yearling and adult females combined. Hatching rate is for all successful nests of yearling and adult females combined. Clutch size is clutch size from all nests of yearling and adult females combined.

for elasticity). The sensitivity and elasticity of vital rates to $\lambda$ varied due to simulated site and year (Fig. 2). Each of the 32 stage- and nest attempt-specific vital rates held at least 8 and as many as 32 different sensitivity ranks. Similarly, each vital rate held at least 12 and as many as 31 different elasticity ranks.

Coefficients of determination were similar whether they were based on raw data or on $\log -\log$ transformed data (i.e., whether changes considered were additive or proportional). Three groups of vital rates, female survival, chick survival, and nest success, accounted for $73-75 \%$ of the variation in $\lambda$. Female survival accounted for $17-18 \%$, chick survival for $22-23 \%$, and nest success for $33-35 \%$.

Several analyses did not substantially change rankings, so we do not present details of their results. These include analyses with correlated vital rates, which were consistent with analyses using uncorrelated rates, and analyses using the $\log -2 \times$ arcsine square root transformation (VSS and its corresponding $R^{2}$ ) which yielded rankings similar to those obtained with the raw data.

Our analyses of other vital rate scenarios indicated quantitative, but not qualitative changes in vital rate importance. Decreasing mean juvenile survival increased the sensitivity and elasticity associated with female survival, and increasing 

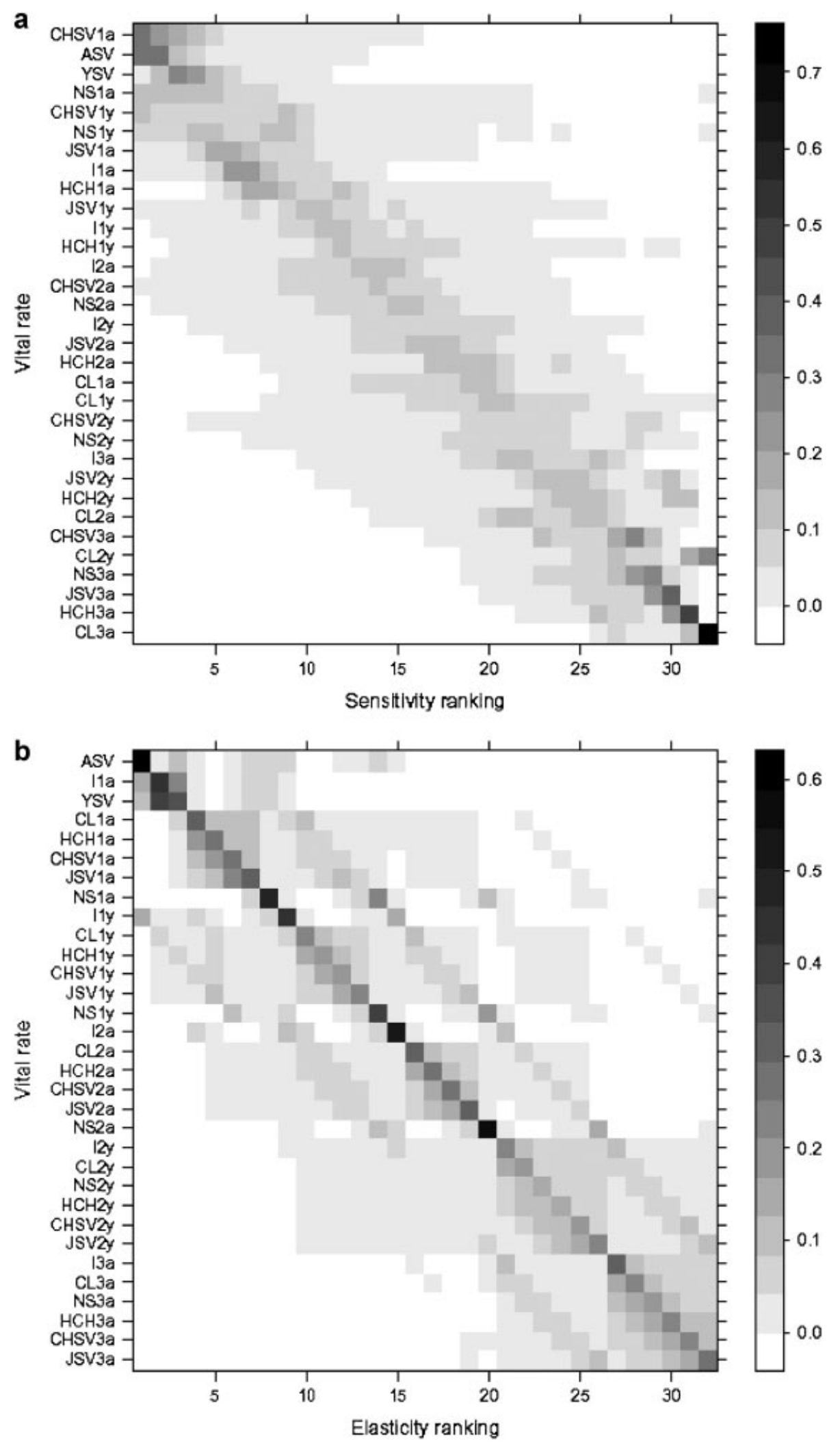

Figure 2. Rankings of sage-grouse vital rates based on (a) sensitivity and (b) elasticity values, from a life-stage simulation analysis using 10,000 simulated matrices derived from range-wide data, 1938-2011. Vital rates are presented in descending order according to their mean sensitivity or elasticity, and shading of squares indicates proportion of simulation replicates in which the vital rate received that rank (legend on right). Vital rate abbreviations are I for nest initiation, CL for clutch size, NS for nest success, HCH for hatching, CHSV for chick survival, JSV for juvenile survival, YSV for yearling survival, and ASV for adult survival. Numbers and letters following abbreviations indicate nesting attempt (1-3) and stage ( $\mathrm{a}=$ adult, $\mathrm{y}=$ yearling). 
mean juvenile survival decreased those metrics. Vital rate rank order, however, did not equalize or change. Increasing mean juvenile survival also caused chick survival to explain relatively more variation in $\lambda$ than female survival by increasing the $R^{2}$ for chick survival and decreasing the $R^{2}$ for female survival. Decreasing mean juvenile survival or increasing its process variance tended to equalize the proportion of variation explained by female survival and chick survival by increasing the $R^{2}$ for female survival and decreasing the $R^{2}$ for chick survival. Increasing process variance of clutch size had negligible effects.

\section{DISCUSSION}

\section{Life History}

Means and variances of vital rates suggest that sage-grouse have a life history strategy intermediate between "highly reproductive" species and "survivor" species (Sæther et al. 1996, Sæther and Bakke 2000). In contrast, almost all other native and introduced North American upland game birds (Phasianidae, Odontophoridae), including ring-necked pheasants (Phasianus colchicus), ruffed grouse (Bonasa umbellus), sharp-tailed grouse and prairie-chickens (Tympanuchus spp.), ptarmigan (Lagopus spp.), partridge (Perdix and Alectoris spp.), and quail (Cyrtonyx, Colinus, Oreortyx, and Callipepla spp.), show traits more representative of "highly reproductive" species, including higher renesting effort, larger clutch sizes, and lower annual survival (Arnold 1988; Jönsson et al. 1991; Rusch et al. 2000; Sandercock et al. 2005, 2008; Clark et al. 2008; Hagen et al. 2009). Although female sage-grouse reach sexual maturity in their first year and have high rates of first nest initiation, they nonetheless have smaller average clutch sizes, lower renesting rates, and higher annual yearling and adult female survival than most other galliforms (Arnold 1988, Jönsson et al. 1991, Connelly et al. 2011). Only 2 other North American galliforms, spruce grouse (Falcipennis canadensis) and dusky grouse (Dendragapus obscurus), both of which inhabit coniferous forests, show life history traits similar to sage-grouse. Compared to sage-grouse, these 2 species have smaller clutch sizes (5-7 eggs), but they have similar reproductive effort relative to body size (clutch mass: body mass ratios of approx. 0.22-0.24) and similar annual female survival (Arnold 1988, Jönsson et al. 1991). Although North American ptarmigan have similar or smaller clutch sizes than sage-grouse, they have higher reproductive effort relative to body size (clutch mass: body mass ratios of approx. 0.29-0.38; Arnold 1988, Braun et al. 1993, Holder and Montgomerie 1993, Hannon et al. 1998).

Although studies at particular locales in Montana (Moynahan et al. 2006) and Utah (Dahlgren 2009) have not detected differences in stage-specific female survival, our range-wide data suggest that, on average, annual survival is higher among yearling females than adult females. Yearling males also have higher survival than do adult males (Swenson 1986, Zablan et al. 2003), although male survival overall is lower than female survival. Juvenile females appear to have similar monthly survival rates as yearling females, at least during fall and winter, but additional studies of juvenile survival are needed to confirm this.

Although female sage-grouse have higher annual survival rates than do other prairie grouse, they are similar to other North American upland game birds in that almost all females attempt to nest every year, and they show high annual variation in productivity. Range-wide data indicate that, on average, after accounting for nest losses prior to detection, $89-96 \%$ or more of female sage-grouse attempt at least 1 nest every year. These results are contrary to the suggestion by Crawford et al. (2004) that low rates of nest initiation contribute to generally low productivity. It is unclear whether low rates of nest initiation reported in some studies (e.g., Gregg 1991, Connelly et al. 1993, Fischer 1994, Chi 2004, Dahlgren 2006, Lowe et al. 2009) are real or due to the logistical difficulties of adequately monitoring females early in the nesting season.

Renesting effort, in contrast, is highly variable. With an average female generation time of $2.5 \mathrm{yr}$, and survival of individual females up to $8 \mathrm{yr}$ (Zablan et al. 2003), females are often able to spread their reproductive effort over more than 1 yr. Parallel patterns of high and low renesting rates between adults and yearlings across years within sites in some studies (Walker 2008) also suggest that females may adjust reproductive effort in any given year in response to environmental conditions. Although both yearlings and adults renested, adults consistently renested at higher rates than yearlings, and only adults attempted third nests. Yearlings also spend less time on the nest and leave the nest more frequently during the day than adults (Coates and Delehanty 2008). Taken together, this suggests that yearling reproductive effort may somehow be constrained by developmental, physiological, or evolutionary factors. Indeed, reduced reproductive effort by females in their first year may be offset by improved subsequent survival due to survival costs associated with brood-rearing (Sika 2006).

Much of the variation in annual productivity and population growth appears to result from substantial variation in sage-grouse nest success and chick survival over time. For example, nest success has been observed to vary by up to 0.3 at the same site in consecutive years (Chi 2004), and in our analyses, it explained more range-wide variation in $\lambda$ than did any other group of vital rates. This may be because nest success is regulated primarily by environmental factors that also fluctuate annually, including the density of nest predators (Coates and Delehanty 2010), vegetation features (e.g., grass height, shrub cover) that mediate predation (Holloran et al. 2005, Coates and Delehanty 2010, Doherty et al. 2010), and weather events that can cause nest failure or abandonment (Walker 2008). Chick survival explained more rangewide variation in $\lambda$ than vital rates other than nest success, and it is known to vary by up to 0.36 in consecutive years at the same site (T. R. Thompson, University of Idaho, unpublished report, T. R. Thompson, K. P. Reese, and A. D. Apa, University of Idaho, unpublished report). Chick survival also appears to be regulated by annually fluctuating environmental factors, such as the density of chick predators, vegetation features that influence chick food sources 
(e.g., forbs and arthropods; Drut et al. 1994) and hiding cover (Gregg and Crawford 2009), weather that kills chicks through exposure (Huwer et al. 2008) or drought (Moynahan 2004), and indirectly by winter and spring precipitation that influences grass and forb growth (Skinner et al. 2002).

Female survival explained the third most range-wide variation in vital rates, following nest success and chick survival. However, because of data limitations, we may have overestimated the mean or underestimated the process variance for juvenile survival. If so, we would have underestimated the importance of female survival, which might, in fact, explain as much variation in $\lambda$ as does chick survival. Overall, sagegrouse show substantial demographic variation among years, which is consistent with substantial fluctuations in sagegrouse population indices (i.e., lek counts) and population size over time (Crawford et al. 2004, Garton et al. 2011).

\section{Model Applications}

Managers would like to know which management strategies are most likely to increase $\lambda$ and, of those, which are both biologically feasible and cost effective (Baxter et al. 2006). Although data on sage-grouse habitat requirements are abundant, and numerous studies have documented correlations between specific vital rates and habitat features, virtually no quantitative, experimental data are available demonstrating how sage-grouse vital rates respond to specific management actions, either positively or negatively. At present, experimental data are limited to the response of nest success to removal of nest predators (Coates and Delehanty 2010). Nevertheless, analytical sensitivities and elasticities indicate that 2 major groups of vital rates, female survival and chick survival, in that order, have the greatest effect on population growth rate, per unit change in vital rates. That is, if management actions could increase female survival or chick survival by the same amount (either additively or proportionally), the greatest gain in population growth rate would be achieved from increasing female survival, and the second largest from increasing chick survival. Nest success had a smaller effect on $\lambda$, per unit change, than did survival; however, because nest success varied widely, it explained more variation in $\lambda$ than did any other group of rates. Manipulative experiments are needed to clarify how much different management actions can change each vital rate and what costs are associated with these actions. With those data in hand, manual perturbations to our demographic model could evaluate the effect of proposed management actions by examining the effect of simultaneous changes in multiple vital rates on population growth. For example, if a hypothetical management action increased nest success by 0.10 and chick survival by 0.07 , but decreased female survival by 0.15 , we would expect population growth rate to decrease by 0.10 .

Our sensitivity results are similar to those of Johnson and Braun (1999), who found that sage-grouse population growth in North Park, Colorado was most sensitive to the combination of chick and juvenile survival, as well as adult female survival, followed by adult and yearling productivity. Our results are also similar to those from the Powder River
Basin of Montana and Wyoming, where female survival, chick survival, and nest success all appeared equally important for population growth (Walker 2008). Sensitivity analysis of a 9-yr sage-grouse dataset in Utah also concluded that adult female survival was the most important vital rate driving population growth (Dahlgren 2009). Overall, accumulated data from local and range-wide populations support the conclusion that population growth in sage-grouse is influenced by multiple vital rates, and that their populations would benefit most from management strategies that simultaneously increase multiple rates, with an emphasis on survival parameters.

Although our analyses identified certain groups of vital rates that were most important on average, they also reflect that the relative contribution of any specific vital rate to $\lambda$ is highly variable (Wisdom and Mills 1997, Mills et al. 1999). Due to substantial, but largely unpredictable, variation in vital rates over time and space, comparison of vital-rate data from short-term datasets to published means may not identify which rates are problematic over the long-term for that population. In other words, results from short-term studies need to be viewed with caution because a perceived demographic problem (e.g., low chick survival) may simply reflect natural annual variation in that vital rate. In contrast, extreme values for vital rates reported over multiple years may be able to identify limiting factors for some populations, particularly when the mechanism is known. As a general guideline for capturing temporal variation in vital rates at a specific site, we suggest sampling for at least $10 \mathrm{yr}$ to encompass the variation that might exist in a decadal population cycle (Rich 1985, Fedy and Doherty 2010).

A coordinated, range-wide effort to collect long-term demographic data on sage-grouse, similar to large-scale efforts undertaken for waterfowl (Hoekman et al. 2002, Coluccy et al. 2008) or ruffed grouse (Devers et al. 2009), would be valuable for addressing life history questions that we were unable to address in this analysis. For example, do life history strategies vary by ecoregion, habitat type, elevation, or migratory status? Although the dataset we used contained data from both fringe (e.g., $\mathrm{AB}, \mathrm{ND}, \mathrm{SD}, \mathrm{WA}$ ) and core populations (MT, WY, ID, eastern OR, NV, northern UT), data for all vital rates were not available from all locations in all years, and some locations were not represented in the data set (e.g., Mono-Lyon, CA-NV). Disproportionate geographic or temporal representation of estimates from ecoregions with different stressors and different population trajectories may have introduced some unknown level of bias into the analysis.

The high average value of $\lambda$ from our matrices is inconsistent with historical population declines observed in portions of the species' range. We believe this may arise from a potentially widespread conundrum for studying species at risk. Most research studies on sage-grouse are attempted where sufficient numbers of females are available for capture and vital rate estimation. Because capture is easiest where populations are large and dense, areas where populations have declined were probably inadequately represented in the dataset. Even in regions with declining populations, the difficulty of capturing females on small leks forces 
researchers to capture birds on the largest of the remaining leks, and these leks likely persist in what is locally the best remaining habitat.

\section{Future Research Needs}

Our literature review revealed 5 basic research needs to maximize the utility of models in guiding sage-grouse management. First, when possible, studies should report vital rates by year, stage, and nest attempt to facilitate population modeling and comparison across studies. For example, many studies that did not report stage-specific survival or nest success estimates could not be included in our analysis (Appendix A, Supplemental Material, available online at www.onlinelibrary.wiley.com). Similarly, few studies reporting chick survival distinguished between survival of chicks from nests of yearling females versus those of adults (Aldridge 2005, Walker 2008). Also, no studies reported stage- or nest attempt-specific hatching rates or juvenile survival.

Second, greater standardization is needed in reporting of vital rates. Many studies reported estimates using different units or over different time periods. Chick survival was commonly reported over different time periods (from hatch to 18-50 days). Numerous studies also reported indices of productivity (e.g., number of chicks per hen in August) rather than estimated chick survival and could not be included in the analysis (e.g., Sveum 1995, Heath et al. 1998, Slater 2003, Kuipers 2004). Time periods for estimates of juvenile survival also varied. Juvenile survival was estimated starting in either August, September, October, or November through the following spring (e.g., Beck et al. 2006, Battazzo 2007, Herman-Brunson 2007, Walker 2008).

Third, increased monitoring intensity in field studies and consistent use of modern analytical techniques for vital-rate estimation would reduce the need for post hoc adjustments. For example, studies reporting only apparent nest initiation and apparent nest success both required adjustments to account for nests depredated prior to discovery and nest losses during the laying period.

Fourth, more study of juvenile survival is needed, particularly between 35 and 60 days of age. Studying early juvenile survival is difficult because juveniles are not fully grown at 35 days and chick-sized transmitters (1-2 g) do not have sufficient battery power to last until birds are old enough (90-120 days) to receive adult-sized transmitters (17-22 g). For that reason, studying early juvenile survival (35-90 days) currently requires recapturing birds and replacing their transmitters twice (T. R. Thompson, unpublished report; T. R. Thompson, K. P. Reese, and A. D. Apa, unpublished report). After 90-120 days, juvenile females are large enough to be marked with adult-sized VHF necklace collars, but tracking birds through their first breeding season is often difficult because sage-grouse are highly mobile and can disperse long distances.

Fifth, techniques for estimating chick survival need to be critically evaluated. The number of studies estimating chick survival has increased rapidly in the past decade as new marking, attachment, and counting techniques for chicks have become available (Burkepile et al. 2002, Aldridge 2005, Gregg et al. 2007, Dahlgren et al. 2010). However, chick survival estimates based on radio-marked chicks may be biased low if capture, handling, or marking increases risk of mortality (Burkepile et al. 2002, Aldridge 2005, Gregg et al. 2007, Rebholz 2007, Gregg and Crawford 2009, Guttery 2011). Studies using chick counts have not, to date, corrected for incomplete detection (e.g., HermanBrunson 2007, Kaczor 2008, Walker 2008, Tack 2009), which can vary from 0.76 for day-time flush counts to $0.96-1.00$ for pointing-dog and spotlight counts (Dahlgren et al. 2010). Furthermore, it is unclear how brood-mixing (Dahlgren 2009) may affect survival estimates from counts. Finally, only some recent studies address the non-independence of survival rates among chicks within the same brood (Aldridge 2005, Dahlgren 2009, Guttery 2011).

\section{MANAGEMENT IMPLICATIONS}

Our results indicate that managers are most likely to increase population growth of sage-grouse by simultaneously managing for 3 major groups of vital rates: female survival, chick survival, and nest success, and by considering how management to benefit one group of vital rates in one season may affect other vital rates during the rest of the year. Managers can boost nest initiation, nest success, and chick survival by ensuring that breeding (e.g., pre-laying, nesting, and early brood-rearing) habitats meet published guidelines for shrub cover, height, and species composition; grass cover and height; and forb abundance at a local scale (Dahlgren et al. 2006, Gregg et al. 2006, Hagen et al. 2007, Kolada et al. 2009, Doherty et al. 2010) and ensuring that sufficient sagebrush dominated habitat remains at patch and landscape scales to support breeding and wintering populations (Aldridge and Boyce 2007; Walker et al. 2007; Aldridge et al. 2008; Doherty et al. 2008, 2010). Ensuring that sufficient amounts of winter habitat with appropriate sagebrush canopy cover (12-43\%) and height $(25-56 \mathrm{~cm}$; Connelly et al. 2000b) are available over large areas is also important to prevent reductions in female survival during severe winters when populations are forced into limited areas where sagebrush remains exposed above the snow (Moynahan et al. 2006, Anthony and Willis 2009). When possible, we also recommend modifying or eliminating anthropogenic features that support predators or are persistent sources of mortality within sage-grouse habitat that, cumulatively, can have a major impact on female survival. These include roads, power lines (Walker et al. 2007, Slater and Smith 2010), stock tanks (Sika 2006), fences (Call and Maser 1985), pesticides (Blus et al. 1989), and water sources that facilitate the spread of West Nile virus (Walker and Naugle 2011). Management actions to enhance survival rates may be most important in seasons when survival is lower: March to November in most years (Schroeder et al. 1999; Connelly et al. 2000b, 2011; Moynahan et al. 2006; Anthony and Willis 2009). Further restricting or eliminating hunting would also remove another persistent and preventable source of sage-grouse mortality in those populations where it is still allowed. Harvest is likely additive to other natural sources of 
sage-grouse mortality when harvest rates exceed a certain proportion of fall population size (approx. 5-11\%; Connelly et al. 2000a, 2003; Sedinger et al. 2010; Reese and Connelly 2011). However, at present, there is little evidence that conservative hunting seasons and bag limits currently in place pose a long-term risk to hunted sage-grouse populations, particularly when sufficient habitat remains and other anthropogenic sources of mortality are controlled (Sedinger et al. 2010, Reese and Connelly 2011). Further restrictions on hunting may also weaken individual incentives to conserve robust, huntable populations and decrease public interest in maintaining sage-grouse habitat (Loveridge et al. 2006). Predator control has also been proposed to increase sage-grouse survival, but it remains a controversial management tool which does not address fundamental habitat alterations, and its long-term consequences to target and non-target species are largely unknown (Schroeder and Baydack 2001).

\section{ACKNOWLEDGMENTS}

We thank J. M. Graham for helpful statistical discussions, and D. Keppie, P.S. Coates, and an anonymous reviewer for comments on the manuscript. We thank numerous authors for contributing additional data, including P. S. Coates, D. K. Dahlgren, M. R. Guttery, D. Hausleitner, D. N. Koons, T. A. Messmer, J. L. Rebholz, and J. D. Tack. We likewise thank Utah State University Extension, Parker Mountain Adaptive Resource Management Working Group (PARM), and the Jack H. Berryman Institute for sharing data. B. L. Walker was supported during this research by the Bureau of Land Management, Department of Energy, National Fish and Wildlife Foundation, an Anheuser-Busch Budweiser Conservation Scholarship, and a Bertha Morton Fellowship from the University of Montana. R. L. Taylor and L. S. Mills were supported by funding from the Bureau of Land Management's Miles City Field Office, and D. E. Naugle was supported by the Bureau of Land Management's Miles City Field Office and the Natural Resources Conservation Service's Sage-grouse Initiative.

\section{LITERATURE CITED}

Aldridge, C. L. 2005. Identifying habitats for persistence of greater sagegrouse (Centrocercus urophasianus) in Alberta, Canada. Dissertation, University of Alberta, Edmonton, Canada.

Aldridge, C. L., and M. R. Boyce. 2007. Linking occurrence and fitness to persistence: habitat-based approach for endangered greater sage-grouse. Ecological Applications 17:508-526.

Aldridge, C. L., S. E. Nielsen, H. L. Beyer, M. S. Boyce, J. W. Connelly, S. T. Knick, and M. A. Schroeder. 2008. Range-wide patterns of greater sage-grouse persistence. Diversity and Distributions 14:983-994.

Anthony, R. J., and M. J. Willis. 2009. Survival rates of female greater sagegrouse in autumn and winter in southeastern Oregon. Journal of Wildlife Management 73:538-545.

Arnold, T. W. 1988. Life histories of North American gamebirds: a reanalysis. Canadian Journal of Zoology 66:1906-1912.

Battazzo, A. M. 2007. Winter survival and habitat use by female greater sage-grouse (Centrocercus urophasianus) in south Phillips County, Montana 2004-2006. Thesis, University of Montana, Missoula, USA.

Baxter, P. W. J., M. A. McCarthy, H. P. Possingham, P. W. Menkhorst, and N. McLean. 2006. Accounting for management costs in sensitivity analyses of matrix population models. Conservation Biology 20:893-905.
Baxter, R. J., J. T. Flinders, and D. L. Mitchell. 2008. Survival, movements, and reproduction of translocated greater sage-grouse in Strawberry Valley, Utah. Journal of Wildlife Management 72:179-186.

Beck, J. L., K. P. Reese, J. W. Connelly, and M. B. Lucia. 2006. Movements and survival of juvenile greater sage-grouse in southeastern Idaho. Wildlife Society Bulletin 34:1070-1078.

Bergerud, A. T. 1988. Increasing the numbers of grouse. Pages 686-731 in A. T. Bergerud and M. W. Gratson, editors. Adaptive strategies and population ecology of northern grouse. University of Minnesota Press, Minneapolis, Minnesota, USA.

Biek, R., W. C. Funk, B. A. Maxell, and L. S. Mills. 2002. What is missing in amphibian decline research: insights from ecological sensitivity analysis. Conservation Biology 16:728-734.

Blus, L. J., C. S. Staley, C. J. Henny, G. W. Pendleton, T. H. Craig, E. H. Craig, and D. K. Halford. 1989. Effects of organophosphorus insecticides on sage-grouse in southeastern Idaho. Journal of Wildlife Management 53:1139-1146.

Bolker, B. E., M. E. Brooks, C. J. Clark, S. W. Geange, J. R. Poulsen, M. H. H. Stevens, and J. S. White. 2008. Generalized linear mixed models: a practical guide for ecology and evolution. Trends in Ecology and Evolution 24:127-135.

Braun, C. E., K. Martin, and L. A. Robb. 1993. White-tailed Ptarmigan (Lagopus leucurus). Account 68 in A. Poole and F. Gill, editors. The birds of North America. The Academy of Natural Sciences, Philadelphia, Pennsylvania, and the American Ornithologists' Union, Washington, D.C., USA.

Burkepile, N. A., J. W. Connelly, D. W. Stanley, and K. P. Reese. 2002. Attachment of radio transmitters to 1-day-old sage-grouse chicks. Wildlife Society Bulletin 30:93-96.

Call, M. W., and C. Maser. 1985. Wildlife habitats in managed rangelands-the Great Basin of southeastern Oregon, Sage Grouse. General Technical Report PNW-187. Pacific Northwest Forest and Range Experiment Station, Portland, Oregon, USA.

Caswell, H. 2001. Matrix population models: construction, analysis, and interpretation. Second edition. Sinauer Associates, Sunderland, Massachusetts, USA.

Chi, R. Y. 2004. Greater sage-grouse on Parker Mountain, Utah. Thesis, Utah State University, Logan, USA.

Clark, W. R., T. R. Bogenschutz, and D. H. Tessin. 2008. Sensitivity analyses of a population projection model of ring-necked pheasants. Journal of Wildlife Management 72:1605-1613.

Coates, P. S., and D. J. Delehanty. 2008. Effects of environmental factors on incubation patterns of Greater Sage-Grouse. Condor 110: 627-638.

Coates, P. S., and D. J. Delehanty. 2010. Nest predation of greater sagegrouse in relation to microhabitat factors and predators. Journal of Wildlife Management 74:240-248.

Coluccy, J. M., T. Yerkes, R. Simpson, J. W. Simpson, L. Armstrong, and J. Davis. 2008. Population dynamics of breeding mallards in the Great Lakes states. Journal of Wildlife Management 72:1181-1187.

Connelly, J. W., A. D. Apa, R. B. Smith, and K. P. Reese. 2000a. Effects of predation and hunting on adult sage grouse Centrocercus urophasianus in Idaho. Wildlife Biology 6:227-232.

Connelly, J. W., and C. E. Braun. 1997. Long-term changes in sage-grouse Centrocercus urophasianus populations in western North America. Wildlife Biology 3:229-234.

Connelly, J. W., R. A. Fischer, A. D. Apa, K. P. Reese, and W. L. Wakkinen. 1993. Renesting by sage-grouse in southeastern Idaho. Condor 95:1041-1043.

Connelly, J. W., C. A. Hagen, and M. A. Schroeder. 2011. Characteristics and dynamics of greater sage-grouse populations. Pages 53-67 in S. T. Knick and J. W. Connelly, editors. Greater sage-grouse: ecology and conservation of a landscape species and its habitats. Studies in Avian Biology, Vol. 38. University of California Press, Berkeley, USA.

Connelly, J. W., S. T. Knick, M. A. Schroeder, and S. J. Stiver. 2004. Conservation assessment of greater sage-grouse and sagebrush habitats. Western Association of Fish and Wildlife Agencies, Cheyenne, Wyoming, USA.

Connelly, J. W., K. P. Reese, E. O. Garton, and M. L. Commons-Kemner. 2003. Response of greater sage-grouse Centrocercus urophasianus populations to different levels of exploitation in Idaho, USA. Wildlife Biology 9:335-340. 
Connelly, J. W., M. A. Schroeder, A. R. Sands, and C. E. Braun. 2000 b. Guidelines to manage sage-grouse populations and their habitats. Wildlife Society Bulletin 28:967-985.

Crawford, J. A., R. A. Olson, N. E. West, J. C. Moseley, M. A. Schroeder, T. D. Whitson, R. F. Miller, M. A. Gregg, and C. S. Boyd. 2004. Ecology and management of sage-grouse and sage-grouse habitat. Journal of Range Management 57:2-19.

Crouse, D. T., L. B. Crowder, and H. Caswell. 1987. A stage-based population model for loggerhead sea turtles and implications for conservation. Ecology 68:1412-1423.

Dahlgren, D. K. 2006. Greater sage-grouse reproductive ecology and response to experimental management of mountain big sagebrush on Parker Mountain, Utah. Thesis, Utah State University, Logan, USA.

Dahlgren, D. K. 2009. Greater sage-grouse ecology, chick survival, and population dynamics, Parker Mountain, Utah. Dissertation, Utah State University, Logan, USA.

Dahlgren, D. K., R. Chi, and T. A. Messmer. 2006. Greater sage-grouse response to sagebrush management in Utah. Wildlife Society Bulletin 34:975-985.

Dahlgren, D. K., T. A. Messmer, E. T. Thacker, and M. R. Guttery. 2010. Evaluation of brood detection techniques: recommendations for estimating greater sage-grouse productivity. Western North American Naturalist 70:233-237.

Devers, P. K., D. F. Stauffer, G. W. Norman, D. E. Steffen, D. M. Whitaker, J. D. Sole, T. J. Allen, S. L. Bittner, D. A. Buehler, J. W. Edwards, D. E. Figert, S. T. Friedhoff, W. W. Giuliano, C. A. Harper, W. K. Igo, R. L. Kirkpatrick, M. H. Seamster, H. A. Spiker, Jr., D. A. Swanson, and B. C. Tefft. 2009. Ruffed grouse population ecology in the Appalachian region. Wildlife Monographs 168:1-36.

Doherty, K. E., D. E. Naugle, and B. L. Walker. 2010. Greater sage-grouse nesting habitat: the importance of managing at multiple scales. Journal of Wildlife Management 74:1544-1553.

Doherty, K. E., D. E. Naugle, B. L. Walker, and J. M. Graham. 2008. Sagegrouse winter habitat selection and energy development. Journal of Wildlife Management 72:187-195.

Drut, M. S., W. H. Pyle, and J. A. Crawford. 1994. Technical note: diets and food selection of sage-grouse chicks in Oregon. Journal of Range Management 47:90-93.

Efron, B., and R. J. Tibshirani. 1998. An introduction to the bootstrap. Monographs on Statistics and Applied Probability 57. CRC Press, Boca Raton, Florida, USA.

Fedy, B. C., and K. E. Doherty. 2010. Population cycles are highly correlated over long time series and large spatial scales in two unrelated species: greater sage-grouse and cottontail rabbits. Oecologia 165:915924.

Fefferman, N. H., and J. M. Reed. 2006. A vital rate sensitivity analysis for nonstable age distributions and short-term planning. Journal of Wildlife Management 70:649-656.

Fischer, R. A. 1994. The effects of prescribed fire on the ecology of migratory sage-grouse in southeastern Idaho. Dissertation, University of Idaho, Moscow, USA.

Garton, E. O., J. W. Connelly, C. A. Hagen, J. S. Horne, A. Moser, and M. A. Schroeder. 2011. Greater sage-grouse population dynamics and probability of persistence. Pages 293-381 in S. T. Knick and J. W. Connelly, editors. Greater sage-grouse: ecology and conservation of a landscape species and its habitats. Studies in Avian Biology, Vol. 38. University of California Press, Berkeley, USA.

Grear J. S., M. W. Meyer, J. H. Cooley, Jr., A. Kuhn, W. H. Piper, M. G. Mitro, H. S. Vogel, K. M. Taylor, K. P. Kenow, S. M. Craig, and D. E. Nacci. 2009. Population growth and demography of common loons in the northern United States. Journal of Wildlife Management 73:1108-1115.

Gregg, M. A. 1991. Use and selection of nesting habitat by sage-grouse in Oregon. Thesis, Oregon State University Corvallis, USA.

Gregg, M. A., and J. A. Crawford. 2009. Survival of greater sage-grouse chicks and broods in the northern Great Basin. Journal of Wildlife Management 73:904-913.

Gregg, M. A., M. R. Dunbar, and J. A. Crawford. 2007. Use of implanted radiotransmitters to estimate survival of greater sage-grouse chicks. Journal of Wildlife Management 71:646-651.

Gregg, M. A., M. R. Dunbar, J. A. Crawford, and M. D. Pope. 2006. Total plasma protein and renesting by greater sage-grouse. Journal of Wildlife Management 70:472-478.
Guttery, M. R. 2011. Ecology and management of a high elevation southern range greater sage-grouse population: vegetation manipulation, early chick survival, and hunter motivations. Dissertation, Utah State University, Logan, USA.

Hagen, C. A., J. W. Connelly, and M. A. Schroeder. 2007. A meta-analysis of greater sage-grouse Centrocercus urophasianus nesting and brood-rearing habitats. Wildlife Biology 13(suppl):42-50.

Hagen, C. A., J. C. Pitman, B. K. Sandercock, R. J. Robel, and R. D. Applegate. 2005. Age-specific variation in apparent survival rates of male lesser prairie-chickens. Condor 107:78-86.

Hagen, C. A., B. K. Sandercock, J. C. Pitman, R. J. Robel, and R. D. Applegate. 2009. Spatial variation in lesser prairie-chicken demography: a sensitivity analysis of population dynamics and management alternatives. Journal of Wildlife Management 73:1325-1332.

Hannon, S. J., P. K. Eason, and K. Martin. 1998. Willow Ptarmigan (Lagopus lagopus). Account 369 in A. Poole and F. Gill, editors. The birds of North America. The Academy of Natural Sciences, Philadelphia, Pennsylvania, and the American Ornithologists' Union, Washington, D.C., USA.

Heath, B., R. Straw, S. Anderson, J. Lawson, and M. Holloran. 1998. Sagegrouse productivity, survival, and seasonal habitat use among three ranches with different livestock grazing, predator control, and harvest management practices. Wyoming Game and Fish Department Completion Report, Cheyenne, USA.

Herman-Brunson, K. M. 2007. Nesting and brood-rearing habitat selection of greater sage-grouse and associated survival of hens and broods at the edge of their historic distribution. Thesis, South Dakota State University, Brookings, USA.

Hoekman, S. T., L. S. Mills, D. W. Howerter, J. H. Devries, and I. J. Ball. 2002. Sensitivity analyses of the life cycle of midcontinent mallards. Journal of Wildlife Management 66:883-900.

Holder, K., and R. Montgomerie. 1993. Rock ptarmigan (Lagopus mutus). Account 51 in A. Poole and F. Gill, editors. The birds of North America. The Academy of Natural Sciences, Philadelphia, Pennsylvania, and the American Ornithologists' Union, Washington, D.C., USA.

Holloran, M. J. 2005. Greater sage-grouse (Centrocercus urophasianus) population response to natural gas field development in western Wyoming. Dissertation, University of Wyoming, Laramie, USA.

Holloran, M. J., B. J. Heath, A. G. Lyon, S. J. Slater, J. L. Kuipers, and S. H. Anderson. 2005. Greater sage-grouse nesting habitat selection and success in Wyoming. Journal of Wildlife Management 69:638-649.

Huwer, S. L., D. R. Anderson, T. E. Remington, and G. C. White. 2008. Using human-imprinted chicks to evaluate the importance of forbs to sage-grouse. Journal of Wildlife Management 72:1622-1627.

Johnson, H. E., L. S. Mills, T. R. Stephenson, and J. D. Wehausen. 2010. Population-specific vital rate contributions influence management of an endangered ungulate. Ecological Applications 20:1753-1765.

Johnson, K. H., and C. E. Braun. 1999. Viability and conservation of an exploited sage-grouse population. Conservation Biology 13:77-83.

Jönsson, K. I., P. K. Angelstam, and J. E. Swenson. 1991. Patterns of life-history and habitat in Palaearctic and Nearctic forest grouse. Ornis Scandanavica 22:275-281.

Kaczor, N. W. 2008. Nesting and brood-rearing success and resource selection of greater sage-grouse in northwestern South Dakota. Thesis, South Dakota State University, Brookings, USA.

Kolada, E. J., M. L. Casazza, and J. S. Sedinger. 2009. Ecological factors influencing nest survival of greater sage-grouse in Mono County, California. Journal of Wildlife Management 73:1341-1347.

Koons, D. N., J. J. Rotella, D. W. Willey, M. Taper, R. G. Clark, S. Slattery, R. W. Brook, R. M. Corcoran, and J. R. Lovvorn. 2006. Lesser Scaup population dynamics: what can be learned from available data? Avian Conservation and Ecology_Écologie et Conservation des Oiseaux 1(3). $<\mathrm{http} / / /$ www.ace-eco.org/vol1/iss3/art6/>. Accessed 1 May 2011.

Kuipers, J. L. 2004. Grazing system and linear corridor influences on greater sage-grouse (Centrocercus urophasianus) habitat selection and productivity. Thesis, University of Wyoming, Laramie, USA.

Link, W. A., and P. F. Doherty, Jr. 2002. Scaling in sensitivity analysis. Ecology 83:3299-3305.

Loveridge, A. J., J. C. Reynolds, and E. J. Milner-Gulland. 2006. Does sport hunting benefit conservation?. Pages 222-240 in D. Macdonald and K. Service, editors. Key topics in conservation biology. Blackwell, London, England. 
Lowe, B. S., D. J. Delehanty, and J. W. Connelly. 2009. Greater sage-grouse Centrocercus urophasianus use of threetip sagebrush relative to big sagebrush in south-central Idaho. Wildlife Biology 15:229-236.

Mills, L. S. 2007. Conservation of wildlife populations: demography, genetics and management. Blackwell, Malden, Massachusetts, USA.

Mills, L. S., D. F. Doak, and M. J. Wisdom. 1999. Reliability of conservation actions based on elasticity analysis of matrix models. Conservation Biology 13:815-829.

Morris, W. F., and D. Doak. 2002. Quantitative conservation biology: theory and practice of population viability analysis. Sinauer Associates, Sunderland, Massachusetts, USA.

Moynahan, B. J. 2004. Landscape-scale factors affecting population dynamics of greater sage-grouse (Centrocercus urophasianus) in north-central Montana, 2001-2004. Dissertation, University of Montana, Missoula, USA.

Moynahan, B. J., M. S. Lindberg, and J. W. Thomas. 2006. Factors contributing to process variance in annual survival of female greater sage-grouse in north-central Montana. Ecological Applications 16: 1529-1538.

Musil, D. D., J. W. Connelly, and K. P. Reese. 1993. Movements, survival, and reproduction of sage grouse translocated into central Idaho. Journal of Wildlife Management 57:85-91.

Raithel, J. D., M. J. Kauffman, and D. H. Pletscher. 2007. Impact of spatial and temporal variation in calf survival on the growth of elk populations. Journal of Wildlife Management 71:795-803.

Rebholz, J. L. 2007. Influence of habitat characteristics on greater sagegrouse reproductive success in the Montana Mountains, Nevada. Thesis, Oregon State University, Corvallis, USA.

Reed, J. M., N. Fefferman, and R. C. Averill-Murray. 2009. Vital rate sensitivity analysis as a tool for assessing management actions for the desert tortoise. Biological Conservation 142:2710-2717.

Reed, J. M., L. S. Mills, J. B. Dunning, Jr., E. S. Menges, K. S. McKelvey, R. Frye, S. Beissinger, M. C. Anstett, and P. Miller. 2002. Emerging issues in population viability analysis. Conservation Biology 16:7-19.

Reese, K. P., and J. W. Connelly. 1997. Translocations of sage grouse Centrocercus urophasianus in North America. Wildlife Biology 3:235-241.

Reese, K. P., and J. W. Connelly. 2011. Harvest management for greater sage-grouse: a changing paradigm for game bird management. Pages 101111 in S. T. Knick and J. W. Connelly, editors. Greater sage-grouse: ecology and conservation of a landscape species and its habitats. Studies in Avian Biology, Vol. 38. University of California Press, Berkeley, USA.

Rich, T. 1985. Sage grouse population fluctuations: evidence for a 10-year cycle. Technical Bulletin 85-1. United States Department of Interior, Bureau of Land Management, Idaho State Office, Boise, USA.

Rusch, D. H., S. DeStefano, M. C. Reynolds, and D. Lauten. 2000. Ruffed Grouse (Bonasa umbellus). Account 515 in A. Poole and F. Gill, editors. The birds of North America. The Academy of Natural Sciences, Philadelphia, Pennsylvania, and the American Ornithologists' Union, Washington, D.C., USA.

Sæther, B. E., and Ä. Bakke. 2000. Avian life-history variation and contribution of demographic traits to the population growth rate. Ecology 81:642-653.

Sæther, B. E., T. H. Ringsby, and E. Roskaft. 1996. Life history variation, population processes and priorities in species conservation: towards a reunion of research paradigms. Oikos 77:217-226.

Sandercock, B. K., W. E. Jensen, C. K. Williams, and R. D. Applegate. 2008. Demographic sensitivity of population change in northern bobwhite. Journal of Wildlife Management 72:970-982.

Sandercock, B. K., K. Martin, and S. J. Hannon. 2005. Life history strategies in extreme environments: comparative demography of arctic and alpine ptarmigan. Ecology 86:2176-2186.

Schroeder, M. A. 2000. Population dynamics of greater and Gunnison sagegrouse: a review. Job Progress Report, Washington Department of Fish and Wildlife, Upland Bird Research, Olympia, USA.

Schroeder, M. A., C. L. Aldridge, A. D. Apa, J. R. Bohne, C. E. Braun, S. D. Bunnell, J. W. Connelly, P. A. Deibert, S. C. Gardner, M. A. Hilliard, G. D. Kobriger, S. M. McAdam, C. W. McCarthy, J. J.
McCarthy, D. L. Mitchell, E. V. Rickerson, and S. J. Stiver. 2004. Distribution of sage-grouse in North America. Condor 106:363-376.

Schroeder, M. A., and R. K. Baydack. 2001. Predation and the management of prairie grouse. Wildlife Society Bulletin 29:24-32.

Schroeder, M. A., J. R. Young, and C. E. Braun. 1999. Sage-grouse (Centrocercus urophasianus). Account 425 in A. Poole and F. Gill, editors. The birds of North America. The Academy of Natural Sciences, Philadelphia, Pennsylvania, and the American Ornithologists' Union, Washington, D.C., USA.

Sedinger, J. S., G. C. White, S. Espinosa, E. T. Partee, and C. E. Braun. 2010. Assessing compensatory versus additive harvest mortality: an example using greater sage-grouse. Journal of Wildlife Management 74:326332.

Sika, J. L. 2006. Breeding ecology, survival rates, and causes of mortality of hunted and nonhunted greater sage-grouse in central Montana. Thesis, Montana State University, Bozeman, USA.

Skinner, R. H., J. D. Hanson, G. L. Hutchinson, and G. E. Schuman. 2002. Response of $\mathrm{C}_{3}$ and $\mathrm{C}_{4}$ grasses to supplemental summer precipitation. Journal of Range Management 55:517-522.

Slater, S. J. 2003. Sage-grouse (Centrocercus urophasianus) use of differentaged burns and the effects of coyote control in southwestern Wyoming. Thesis, University of Wyoming, Laramie, USA.

Slater, S. J., and J. P. Smith. 2010. Effectiveness of raptor perch deterrents on an electrical transmission line in southwestern Wyoming. Journal of Wildlife Management 74:1080-1088.

Stahl, J. T., and M. K. Oli. 2006. Relative importance of avian life-history variables to population growth rate. Ecological Modelling 198:23-39.

Sveum, C. M. 1995. Habitat selection by sage-grouse hens during the breeding season in southcentral Washington. Thesis, Oregon State University, Corvallis, USA.

Swanson, C. C. 2009. Ecology of greater sage-grouse in the Dakotas. Dissertation, South Dakota State University, Brookings, USA.

Swenson, J. E. 1986. Differential survival by sex in juvenile sage-grouse and gray partridge. Ornis Scandinavica 17:14-17.

Tack, J. D. 2009. Sage-grouse and the human footprint: implications for conservation of small and declining populations. Thesis, University of Montana, Missoula, USA.

United States Fish and Wildlife Service. 2010. 12-month finding for petitions to list the greater sage-grouse (Centrocercus urophasianus) as threatened or endangered. Federal Register 75(55):13909-14014.

Walker, B. L. 2008. Greater sage-grouse response to coal-bed natural gas development and West Nile virus in the Powder River Basin, Montana and Wyoming, USA. Dissertation, University of Montana, Missoula, USA.

Walker, B. L., and D. E. Naugle. 2011. West Nile virus ecology in sagebrush habitat and impacts on greater sage-grouse populations. Pages 127-142 in S. T. Knick and J. W. Connelly, editors. Greater sage-grouse: ecology and conservation of a landscape species and its habitats. Studies in Avian Biology, Vol. 38. University of California Press, Berkeley, USA.

Walker, B. L., D. E. Naugle, and K. E. Doherty. 2007. Greater sage-grouse population response to habitat loss and coal-bed natural gas development. Journal of Wildlife Management 71:2644-2654.

Wallestad, R. O. 1975. Life history and habitat requirements of sage-grouse in central Montana. Montana Department of Fish, Game, and Parks, Helena, USA.

Wisdom, M. J., and L. S. Mills. 1997. Sensitivity analysis to guide population recovery: prairie-chickens as an example. Journal of Wildlife Management 61:302-312.

Wisdom, M. J., L. S. Mills, and D. F. Doak. 2000. Life state simulation analysis: estimating vital rate effects on population growth for species conservation. Ecology 81:628-641.

Zablan, M. A., C. E. Braun, and G. C. White. 2003. Estimation of greater sage-grouse survival in North Park, Colorado. Journal of Wildlife Management 67:144-154.

Associate Editor: Peter Coates. 